\title{
Physiological responses to hypoxia and anoxia in Balanus amphitrite (Cirripedia: Thoracica)
}

\author{
Dattesh V. Desai*, S. Prakash \\ National Institute of Oceanography, Council of Scientific and Industrial Research, Dona Paula, Goa 403 004, India
}

\begin{abstract}
The barnacle Balanus amphitrite Darwin is a dominant intertidal and major fouling organism. As its life cycle includes both sessile and pelagic phases, adaptation is a necessity to tolerate harsh conditions that are faced in the intertidal and pelagic environment. A downward trend in dissolved oxygen levels in coastal areas has been recently observed, which would have a more prominent effect on sessile organisms inhabiting the intertidal habitats. The effects of reduced dissolved oxygen levels (hypoxia) and no oxygen (anoxia) on B. amphitrite adults and nauplii was assessed. Their response was evaluated by estimating the levels of the antioxidant enzymes catalase and superoxide dismutase. The impact of desiccation on antioxidant enzymes in adult B. amphitrite collected from different tidal heights was also evaluated. When nauplii were starved, $100 \%$ mortality was observed after $64 \mathrm{~h}$ under hypoxia, and between 24 and $32 \mathrm{~h}$ under anoxia. However, when nauplii were exposed to hypoxia and anoxia along with food, their tolerance level increased. A decrease in naupliar feeding rate and oxygen consumption was observed when they were exposed to hypoxia and anoxia. A significant difference in the levels of antioxidant enzymes in adult $B$. amphitrite collected at different tidal levels was observed. Enzyme activity increased with increase in the duration of tidal exposure, suggesting a capability to adapt to stress in different niches. Nauplii showed antioxidant defense (increased enzyme activity) under hypoxia and anoxia. The magnitude of change in enzyme levels suggests that these enzymes could be potential biomarkers of stress.
\end{abstract}

KEY WORDS: Balanus amphitrite $\cdot$ Desiccation $\cdot$ Hypoxia $\cdot$ Anoxia $\cdot$ Catalase $\cdot$ Superoxide dismutase Resale or republication not permitted without written consent of the publisher

\section{INTRODUCTION}

On the edge of any static body of water there is a gradation of environmental conditions from terrestrial to aquatic, and this is paralleled by changes in the nature of the organisms. The situation is made more complex in coastal environments by the semidiurnal rise and fall of the tide, which results in periodic exposure and emersion of the intertidal zone, and coastal environments also have spatially and temporally varying physico-chemical factors (Newell 1979).

Barnacles are characteristic intertidal sessile rockyshore organisms (Stephenson \& Stephenson 1972). When environmental factors become adverse, the adaptations of barnacles to extreme conditions include increased tolerance or mechanisms to protect tissues under all likely conditions, both physically and physiologically.
The barnacle Balanus amphitrite (= Amphibalanus amphitrite) (Clare \& Høeg 2008) inhabits the intertidal region in the coastal marine environment and is also a dominant fouling organism (Fernando 1990, Anil 1991, Desai \& Anil 2005). The life cycle of B. amphitrite includes both sessile (juvenile and adult) and pelagic (nauplii and cypris) phases. The adult releases instar I nauplii, which molt into instar II within a short duration ( 2 to $3 \mathrm{~h}$ ). From instar II to instar VI they undergo a planktotrophic naupliar development. Instar VI nauplii undergo metamorphosis into a cypris larva, which is a nonfeeding stage. The cypris larva searches for a suitable substratum on which to settle. Thus, all the stages of the barnacle life cycle should adapt to tolerate any harsh conditions occurring at the air-water interface in the intertidal region and also in the pelagic environment to successfully complete the planktonic phase. 
In recent years a downward trend in the levels of dissolved oxygen (DO) has been observed in coastal areas worldwide (Diaz 2001). Concern over the health of estuarine habitats has prompted researchers to shift their attention to the responses of organisms to low oxygen conditions, i.e. hypoxia. The seasonal shifts in the spatial distribution of oxygen levels can result in a dramatic shift in the composition of benthic and pelagic communities and the availability of the habitat to estuarine species. Oxygen depletion occurs more frequently in coastal areas with longer water residence time, higher nutrient loads and stratified water columns (Harned \& Davenport 1990, Breitburg 1992, Howell \& Simpson 1994, Paerl et al. 1998, Diaz 2001). No other environmental variable of such ecological importance to estuarine and coastal marine ecosystems around the world has changed so drastically in a short period of time as DO, and this is an issue of growing global concern.

Release of larvae in hypoxic or anoxic waters could have an impact on their survival and development during the planktonic phase of their life cycle. Investigations have been carried out with barnacles on their capacity to withstand desiccation, habitat selection, life-cycle stages, planktotrophic larval dispersal, biological factors such as abundance of phytoplankton on naupliar development, and importance in marine fouling (Crisp 1954, Barnes \& Barnes 1968, Hurley 1973, Lewis 1975, Khandeparker et al. 2003, Desai \& Anil 2004, Richardson \& Brown 1990).

In barnacles, respiratory exchange is regulated during altered $\mathrm{pH}$ and, to a lesser extent, oxygen tension, by modification of the duration of activity bursts and not altering the frequency of the cirral beat (Southward \& Crisp 1965). Barnacles resist the entry of water into the mantle cavity by controlled use of the opercular valves (Foster 1970). However, anoxic metabolism in barnacles has not been well documented. Lopez et al. (1995) reported that the presence of predators can also lead to prolonged closure of valves in barnacles and this may provoke an anoxic condition, even during immersion. Oxygen is essential for most life forms, but it is also inherently toxic due to its biotransformation into reactive oxygen species (ROS). A direct consequence of hypoxic environment is the production of deleterious ROS generated by the reduction of molecular oxygen to water by the addition of 4 electrons (Di Giulio et al. 1989). Organisms are able to adapt to some chronic situations of high exposure to ROS by increasing the levels of antioxidant enzymes, many other forms of defense or response and repair of oxidative damage (Halliwell \& Gutteridge 1986, Demple 1999). Key enzymatic players in such defense mechanisms against ROS include catalase, superoxide dismutases, glutathione reductases, glutathione peroxidases, and glutathione S-transferases. Variations in the levels or activity of antioxidant defenses have often been used to indicate ROS-mediated toxicity (Halliwell 1978, Halliwell \& Gutteridge 1986, Pryor \& Godber 1991, Winston \& Di Giulio 1991, Ahmad 1995).

Balanus amphitrite is regularly exposed in the intertidal area of the study region (Dona Paula Bay, India) to tidal fluctuations from 0.25 to $2.5 \mathrm{~m}$. The present study was conducted to assess (1) the impact of desiccation on the antioxidant defense of adult barnacles collected from different tidal levels from the field, (2) the influence of hypoxia and anoxia on $B$. amphitrite adults and nauplii in the laboratory, and (3) the influence of hypoxia and anoxia on larval survival, food ingestion rate, and oxygen consumption in the laboratory.

\section{MATERIALS AND METHODS}

Study site and barnacle collection. The intertidal area of Dona Paula Bay $\left(15^{\circ} 27.5^{\prime} \mathrm{N}, 73^{\circ} 48^{\prime} \mathrm{E}\right)$, situated at the mouth of the Zuari estuary along the central west coast of India, was selected as the study site. The local tidal amplitude ranges from $0.25 \mathrm{~m}$ during neap tides to $2.5 \mathrm{~m}$ during spring tides. Perennial connections of this estuary with the Arabian Sea result in a regular exchange of marine and estuarine plankton populations (Devassy \& Goes 1989). The study site is influenced by the monsoons from the southwest.

Adult Balanus amphitrite were collected from the intertidal area of this bay, brought to the laboratory, exposed to air for a short duration ( 30 $\mathrm{min}$ ) and then placed in seawater, which triggered the release of instar I nauplii. The non-feeding instar I nauplii molted into instar II nauplii and these were subsequently used to carry out different experiments. The main reason for using instar II nauplii was that, being the first feeding stage of barnacle naupliar development, they would also be the first stage to be affected by the stress induced by both physical and biological parameters.

Hypoxic and anoxic seawater. A reservoir containing filtered seawater of $35 \%$ was deoxygenated by continuous bubbling of dry nitrogen gas for 2 to $3 \mathrm{~h}$ prior to incubation (Widdows et al. 1989). Syringes $(100 \mathrm{ml})$ were used for removing the hypoxic seawater from the reservoir without exposing the water to the surrounding atmosphere. This seawater was immediately fixed with Winkler's reagents to quantify the DO at $0.5\left(\mathrm{DO}_{0.5}\right)$ and $1\left(\mathrm{DO}_{1.0}\right) \mathrm{ml} \mathrm{l}^{-1}$. Anoxic seawater (i.e. no oxygen) was obtained by bubbling filtered seawater with dry nitrogen gas for a longer duration.

Larval development under hypoxia and anoxia. Hypoxic seawater was taken from the reservoir using syringes and transferred to $30 \mathrm{ml}$ DO bottles without exposure to the surroundings. Instar II nauplii were 
incubated in hypoxic seawater $\left(\mathrm{DO}_{0.5}\right.$ and $\left.\mathrm{DO}_{1.0}\right)$ in the $30 \mathrm{ml}$ DO bottles. Thirty individuals were taken for the developmental studies (i.e. 1 larva $\mathrm{ml}^{-1}$ ). Control bottles were maintained separately, with an oxygen level of $5 \mathrm{ml} \mathrm{l}^{-1}$. Observations on naupliar mortality and molting were taken from each DO bottle after $24 \mathrm{~h}$. Surviving nauplii were transferred to fresh DO bottles with hypoxic seawater at the same DO concentrations as they were in the first bottle or at the start of the experiment, and food. Similar experiments were carried out with anoxic seawater. All experiments were repeated 3 times.

Oxygen consumption by adults and nauplii. Oxygen consumption by adults and nauplii in control and hypoxic conditions was observed in the laboratory at $25 \pm 1{ }^{\circ} \mathrm{C}$ temperature and $35 \%$ salinity. Adult barnacles collected from Dona Paula Bay were brought to the laboratory, cleaned of epibiotic growth using a nylon brush, and acclimatized in the laboratory for $24 \mathrm{~h}$. Then 5 adults of 12 to $14 \mathrm{~mm}$ rostro carinal diameter (RCD) were chosen for evaluating oxygen consumption. They were incubated in $60 \mathrm{ml}$ DO bottles in $0.22 \mu \mathrm{m}$ filtered seawater in the dark under normal oxygen conditions without food and observed after $24 \mathrm{~h}$ (Strickland \& Parsons 1968). Similarly, 5 adults of 12 to $14 \mathrm{~mm}$ RCD were chosen and incubated in $60 \mathrm{ml}$ DO bottles for $24 \mathrm{~h}$ in hypoxic seawater $\left(\mathrm{DO}_{0.5}\right.$ and $\mathrm{DO}_{1.0}$ ) in the dark for evaluating oxygen consumption and these experiments were repeated 3 times with different batches of adults.

Oxygen consumption by instar II nauplii was measured after incubation for $24 \mathrm{~h}$ in filtered $(0.22 \mu \mathrm{m})$ seawater $\left(5 \mathrm{ml} \mathrm{l}^{-1} \mathrm{DO}\right)$ in $60 \mathrm{ml}$ DO bottles, without food and in the dark. These conditions were treated as the control. Instar II nauplii were incubated in hypoxic seawater $\left(\mathrm{DO}_{0.5}\right.$ and $\left.\mathrm{DO}_{1.0}\right)$ without food in $60 \mathrm{ml} \mathrm{DO}$ bottles in dark. A set of 8 bottles with 60 nauplii in each (i.e. 1 larva $\mathrm{ml}^{-1}$ ) was maintained for prolonged exposure to hypoxic seawater, as well as the control. Each bottle with nauplii was sacrificed every $8 \mathrm{~h}$ for measuring mortality and DO levels. The experiment was repeated 3 times with different batches of larvae.

Naupliar ingestion rate. Filtered $(0.22 \mu \mathrm{m})$ seawater containing the diatom Chaetoceros calcitrans $(1 \times$ $10^{5}$ cells ml ${ }^{-1}$ ) was deoxygenated by bubbling with dry nitrogen gas until 0.5 and $1 \mathrm{ml} \mathrm{l}^{-1}$ DO levels were obtained. The instar II nauplii (30 ind.) were then transferred to this hypoxic seawater with food in DO bottles $(30 \mathrm{ml})$ and incubated in the dark. Observations were made on the feeding rate at the end of $24 \mathrm{~h}$ by counting the number of $C$. calcitrans cells and correcting against the increase in C. calcitrans cells in the control (without larvae). Similar experiments were carried out under anoxic conditions. The experiments were repeated 3 times with different batches of larvae.
Antioxidant enzyme activity. Organism incubation: Adult barnacles were collected from the field at 3 tidal levels (low, mid, and high) from the intertidal area during low tide. These barnacles were immediately transferred to ice and brought to the laboratory under cold conditions and stored at $-20^{\circ} \mathrm{C}$ until required for the enzyme assays. To estimate the antioxidant enzymes in adult barnacles under hypoxia and anoxia, adult barnacles (10 to $14 \mathrm{~mm} \mathrm{RCD)} \mathrm{collected} \mathrm{from} \mathrm{the} \mathrm{field} \mathrm{were}$ brought to the laboratory and acclimatized to laboratory conditions for $24 \mathrm{~h}$. Five individuals (in 3 sets) were then placed in hypoxic $\left(\mathrm{DO}_{0.5}\right.$ and $\left.\mathrm{DO}_{1.0}\right)$ and anoxic seawater and antioxidant enzyme activity was analyzed after $24 \mathrm{~h}$ of incubation. Adults maintained in normal seawater with aeration were used as the control. The experiments were repeated with different batches of adults.

Similarly, to estimate the antioxidant enzyme activity in the nauplii exposed to hypoxia and anoxia, instar II nauplii (60 ind.) were incubated in hypoxic $\left(\mathrm{DO}_{0.5}\right.$ and $\mathrm{DO}_{1.0}$ ) and anoxic seawater in $60 \mathrm{ml} \mathrm{DO}$ bottles (i.e. 1 larva $\mathrm{ml}^{-1}$ ). After $24 \mathrm{~h}$, nauplii were sampled from the DO bottles and their antioxidant enzyme activity was estimated. Instar II nauplii incubated in normal seawater $\left(5 \mathrm{ml} \mathrm{l}^{-1} \mathrm{DO}\right)$ for $24 \mathrm{~h}$ were used as the control.

Sample preparation and assay: Adults stored at $-20^{\circ} \mathrm{C}$ were taken out and the soft body was dissected out by breaking the shell plates. The tissue was then rinsed with cold distilled water and homogenized using glass homogenizer. Extraction was done by using $1 \mathrm{mM}$ EDTA, sodium phosphate buffer (20 mM at pH 7.4), and Triton X-100 (0.1\%) (Mourente et al. 1999). For this, 9 volumes of each solution were added one by one to the soft tissue before homogenization. The homogenized mixture was centrifuged at $4^{\circ} \mathrm{C}$ and $600 \times g$ for $10 \mathrm{~min}$. Supernatant was collected and used for enzyme assays. A similar procedure was used to extract enzymes from the adult barnacles and nauplii exposed to hypoxia and anoxia in the laboratory and for adult and nauplii maintained under control conditions. The total protein concentration was determined by the method described by Lowry et al. (1951), using bovine serum albumin as the standard.

Catalase: Catalase activity was determined spectrophotometrically by measuring the rate of enzymatic decomposition of $\mathrm{H}_{2} \mathrm{O}_{2}$, determined at an absorbance of $570 \mathrm{~nm}$ (Sinha 1972). The activity of catalase was expressed as follows: 1 unit of catalase is the amount of enzyme that utilizes $1 \mu \mathrm{M}$ of $\mathrm{H}_{2} \mathrm{O}_{2}$. Standardization was carried out using different concentrations of enzyme that were used to measure the decomposition of different amounts $(\mu \mathrm{M})$ of $\mathrm{H}_{2} \mathrm{O}_{2}$.

Superoxide dismutase: Superoxide dismutase activity was determined spectrophotometrically following a simple and rapid method (Marklund \& Marklund 1974). The enzyme activity was measured as the de- 
gree of inhibition of autoxidation of pyrogallol, at an alkaline $\mathrm{pH}$, by superoxide dismutase. It is expressed as 1 unit of enzyme that corresponds to the amount of enzyme that inhibits $50 \%$ autoxidation of pyrogallol.

Standards were prepared using pyrogallol at different concentrations (Marklund \& Marklund 1974). Autoxidation of pyrogallol was tested using $1 \mathrm{mM}$ EDTA and Tris-cacodylic acid buffer at $\mathrm{pH}$ 8.2. Increasing concentrations of pyrogallol were prepared in buffer from 0.1 to $0.5 \mathrm{mM}$. These standards were prepared and analyzed as per the procedure of Marklund \& Marklund (1974) and the rate of autoxidation of increased concentration of pyrogallol was detected at $420 \mathrm{~nm}$. The observations were made from 1 to $3 \mathrm{~min}$ to detect the rate of autoxidation $\mathrm{min}^{-1}$. Enzyme standards were prepared with the increasing concentrations and presented in units $\mathrm{ml}^{-1}$.

\section{RESULTS}

\section{Effects of hypoxia and anoxia on larvae under starvation}

After $8 \mathrm{~h}$ of exposure the initial mortality was $8 \%$ in seawater with $\mathrm{DO}_{0.5}, 3 \%$ in $\left(\mathrm{DO}_{1.0}\right)$ and $1 \%$ in control (Fig. 1). Mortality increased with the duration of exposure. A $50 \%$ mortality was observed between 40 and $48 \mathrm{~h}$ in seawater with $\mathrm{DO}_{1.0}$ and between 32 and $40 \mathrm{~h}$ in $\mathrm{DO}_{0.5}$ (Fig. 1). Under anoxic conditions, $100 \%$ mortality was observed between 24 and $32 \mathrm{~h}$ of exposure (Fig. 1). Two-way ANOVA results indicated a significant $(p \leq 0.04)$ influence of DO concentration with the duration of exposure on larval mortality.

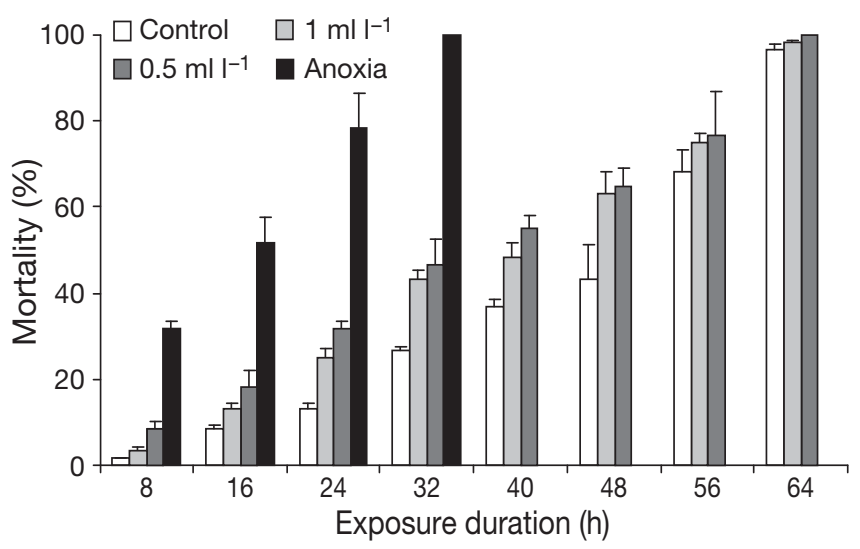

Fig. 1. Balanus amphitrite. Effect of normoxia (control), hypoxia $\left(0.5\right.$ and $\left.1 \mathrm{ml} \mathrm{l}^{-1}\right)$, and anoxia on mortality of nauplii under starvation. In anoxia treatment, all nauplii were dead after $32 \mathrm{~h}$ of exposure, so no data are presented beyond $32 \mathrm{~h}$.

Error bars: +SD
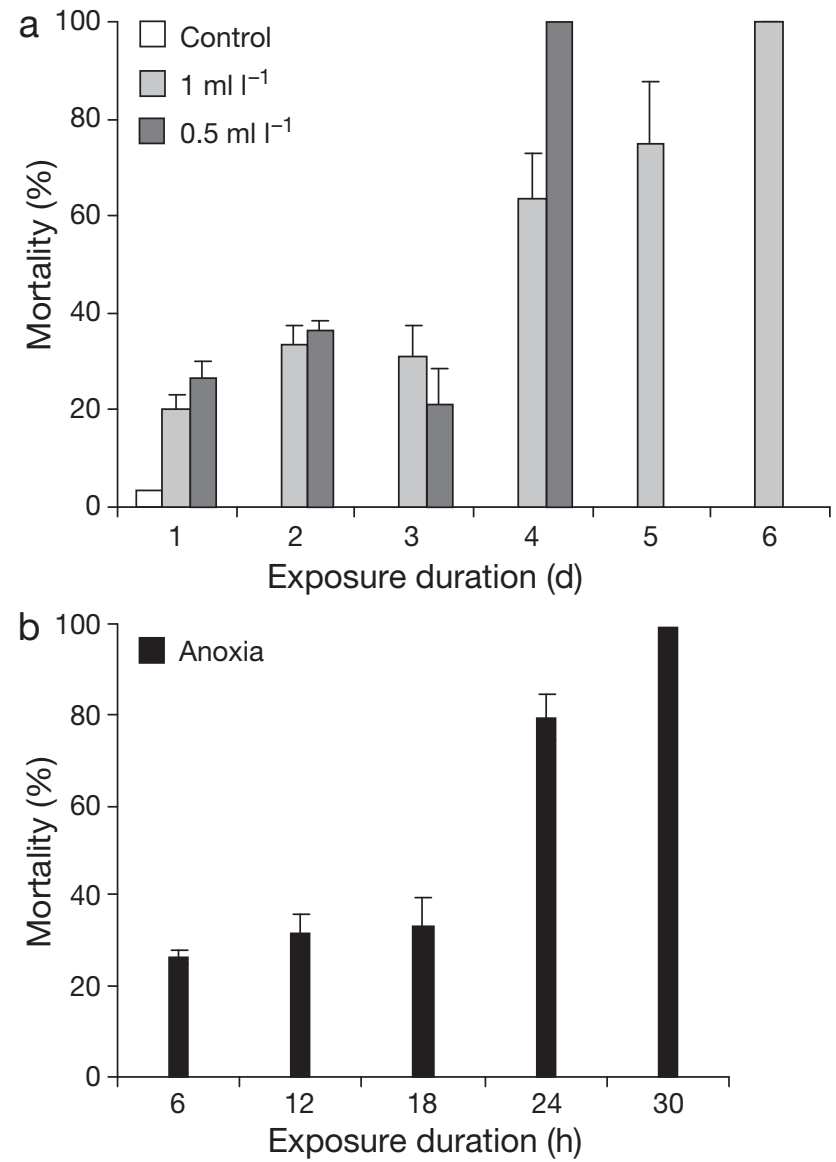

Fig. 2. Balanus amphitrite. Effect of (a) hypoxia (0.5 and $1 \mathrm{ml}$ $\mathrm{l}^{-1}$ ) and normoxia (control) and (b) anoxia on mortality of nauplii when fed Chaetoceros calcitrans. In control conditions, mortality was observed only on Day 1. Error bars: +SD

\section{Effect of hypoxia and anoxia on larvae in the presence of food}

After $1 \mathrm{~d}$ of exposure, $20 \%$ mortality was observed in $\mathrm{DO}_{1.0}$ and $26 \%$ in $\mathrm{DO}_{0.5}$ (Fig. 2a). Mortality was $100 \%$ after 4 and $6 \mathrm{~d}$ exposure in $\mathrm{DO}_{0.5}$ and $\mathrm{DO}_{1.0}$, respectively (Fig. 2a). Only $3 \%$ mortality was observed in the control throughout the experiment (Fig. 2a). Two-way ANOVA results indicated a significant variation ( $p \leq 0.006)$ in the mortality rate of the nauplii when treated in different concentrations of DO. Under anoxic conditions, $100 \%$ mortality of nauplii was observed after $30 \mathrm{~h}$ of exposure (Fig. 2b). When we compared the mortality of nauplii under anoxic conditions in the presence and absence of food, $100 \%$ mortality was observed after about $30 \mathrm{~h}$ in both cases. However, this was not the case under hypoxic conditions; $100 \%$ mortality was observed after $64 \mathrm{~h}$ (at $\mathrm{DO}_{0.5}$ and $\mathrm{DO}_{1.0}$ ) under starving conditions and after 4 and $6 \mathrm{~d}$ at $\mathrm{DO}_{0.5}$ and $\mathrm{DO}_{1.0}$, respectively, under feeding conditions. 


\section{Oxygen consumption}

Oxygen consumption by Balanus amphitrite larvae was observed at ambient oxygen concentrations. A significant difference (1-way ANOVA; $\mathrm{p} \leq 0.006)$ in the consumption of DO was observed under normal DO concentrations $\left(7.6 \times 10^{-5} \mathrm{ml} \mathrm{l}^{-1}\right.$ larva $\left.^{-1} \mathrm{~h}^{-1}\right)$ and a reduction in the utilization of DO by larvae was observed with a decrease in DO levels $\left(3.15 \times 10^{-6} \mathrm{ml} \mathrm{l}^{-1}\right.$ larva $^{-1}$ $\mathrm{h}^{-1}$ at $\mathrm{DO}_{0.5}$ and $9.5 \times 10^{-6} \mathrm{ml} \mathrm{l}^{-1}$ larva $^{-1} \mathrm{~h}^{-1}$ at $\mathrm{DO}_{1.0 \text {, }}$ respectively) (Fig. 3a). A similar trend was also observed in adults exposed to different DO concentrations. An oxygen consumption of $1.35 \times 10^{-3} \mathrm{ml} \mathrm{l}^{-1} \mathrm{~h}^{-1}$ $\mathrm{mg}^{-1}$ wet wt was observed in normal DO conditions, and $2.25 \times 10^{-4}$ and $6.35 \times 10^{-5} \mathrm{ml} \mathrm{l}^{-1} \mathrm{~h}^{-1} \mathrm{mg}^{-1}$ wet wt at $\mathrm{DO}_{0.5}$ and $\mathrm{DO}_{1.0}$, respectively (Fig. 3b). One-way ANOVA results indicated a significant variation $(\mathrm{p} \leq$ 0.0001 ) in the oxygen consumption levels with different concentrations of DO.

\section{Ingestion rate}

Ingestion of Chaetoceros calcitrans cells by Balanus amphitrite nauplii was observed at reduced DO levels.
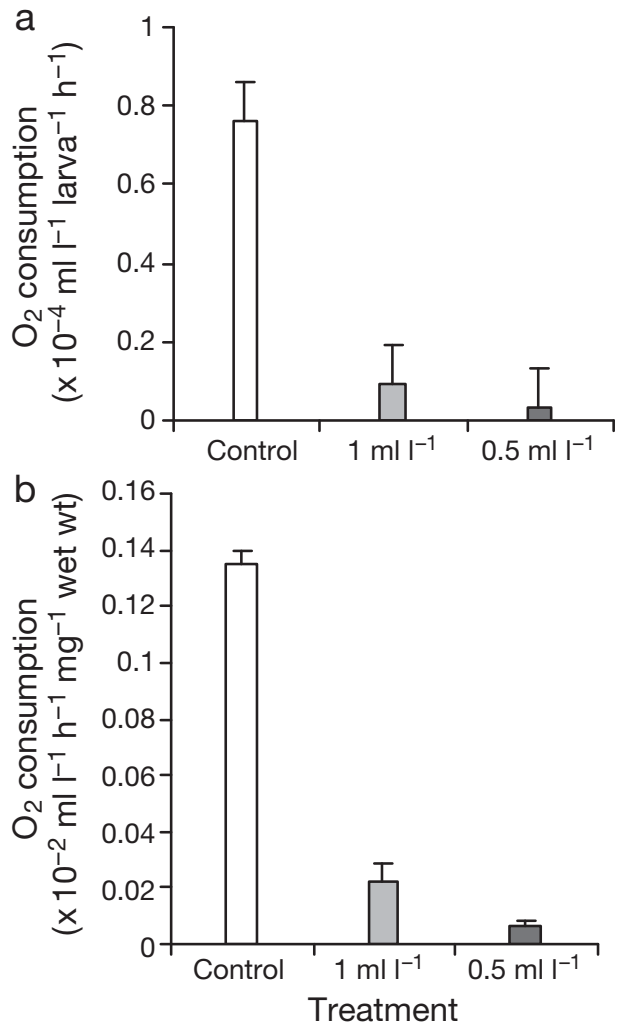

Fig. 3. Balanus amphitrite. Oxygen consumption under normoxia (control) and hypoxia $\left(0.5\right.$ and $\left.1 \mathrm{ml} \mathrm{l}^{-1}\right)$ by (a) nauplii and (b) adults. Error bars: +SD

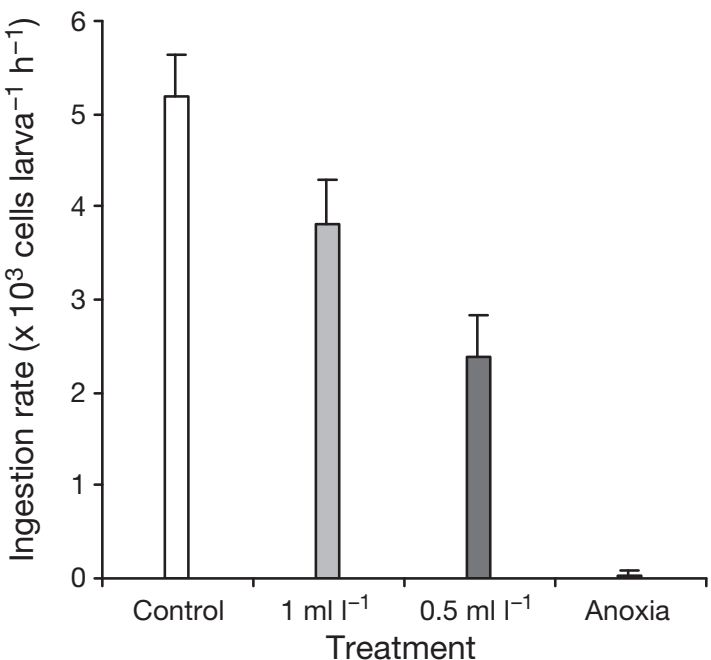

Fig. 4. Balanus amphitrite. Ingestion rates of Chaetoceros calcitrans by nauplii under hypoxia $\left(0.5\right.$ and $\left.1 \mathrm{ml} \mathrm{l}^{-1}\right)$, anoxia and normoxia (control). Error bars: + SD

The ingestion rate varied with the DO concentration (1-way ANOVA; $\mathrm{p} \leq 0.0008)$. Consumption of 5500 cells larva ${ }^{-1} \mathrm{~h}^{-1}$ was observed at normal DO conditions and was reduced to 4000 cells larva ${ }^{-1} \mathrm{~h}^{-1}$ at $\mathrm{DO}_{1.0}$ and 2700 cells larva ${ }^{-1} \mathrm{~h}^{-1}$ at $\mathrm{DO}_{0.5}$ (Fig. 4). Food consumption was negligible when nauplii were exposed to anoxia (Fig. 4).

\section{Enzyme activity in Balanus amphitrite collected from the field}

A significant difference in catalase activity was observed among the adults collected at 3 tidal exposure levels (1-way ANOVA $;$ p $\leq 0.0002$ ). Adults from the low tidal level showed low catalase activity when compared with adults from the mid- and high tidal regions (Fig. 5a). The amount of catalase was 6.83, 7.8, and $8.42 \mathrm{U} \mathrm{mg}^{-1}$ protein in adults collected from low, mid-, and high tidal regions respectively (Fig. 5a). Superoxide dismutase activity in these adults also showed an increase with the exposure duration. The amount of superoxide dismutase in the adult Balanus amphitrite increased from low (4.06 $\mathrm{U} \mathrm{mg}^{-1}$ protein) to high (6.14 $\mathrm{U} \mathrm{mg}^{-1}$ protein) tidal level. At the mid-tidal level, the superoxide dismutase activity was $5.2 \mathrm{U} \mathrm{mg}^{-1}$ protein (Fig. 5b).

\section{Enzyme activity in adults under hypoxia and anoxia}

Adults in control conditions showed very low catalase activity (Fig. 6a). However, at $\mathrm{DO}_{1.0}$ and $\mathrm{DO}_{0.5}$, catalase activity was 4.15 and $5.57 \mathrm{U} \mathrm{mg}^{-1}$ protein, 

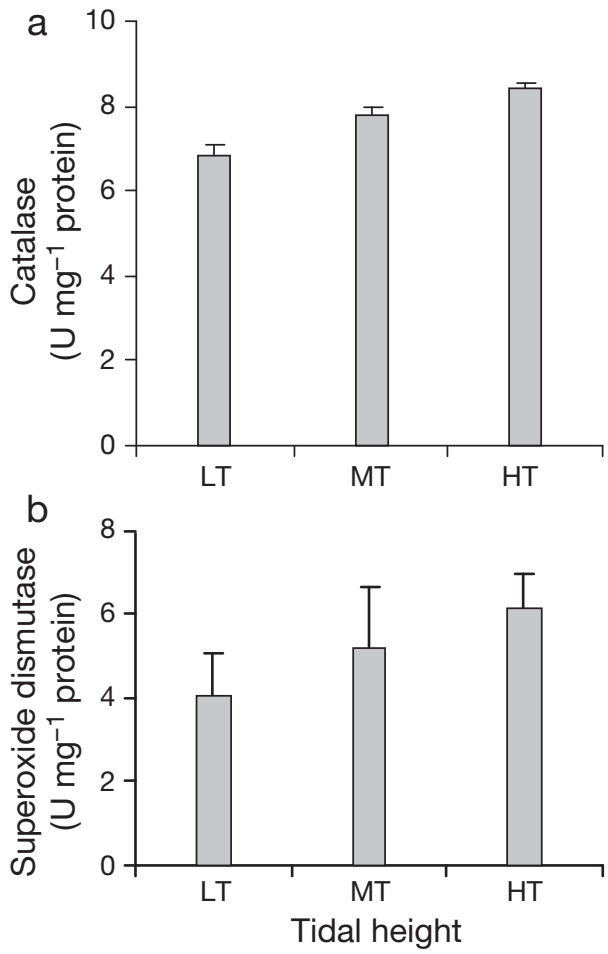

Fig. 5. Balanus amphitrite. Activity of (a) catalase and (b) superoxide dismutase in adults collected from low (LT), mid(MT), and high (HT) tidal regions. Error bars: + SD

respectively (1-way ANOVA; $\mathrm{p} \leq 0.000007)$. The maximum catalase activity of $7.08 \mathrm{U} \mathrm{mg}^{-1}$ protein was observed when the barnacles were exposed to anoxic conditions (Fig. 6a). Superoxide dismutase activity showed a similar trend. A significant increase in superoxide dismutase activity was observed with a decreasing concentration of DO (1-way ANOVA; $\mathrm{p} \leq 0.001)$. The control showed very low enzyme activity. Enzyme activity was $5.82 \mathrm{U} \mathrm{mg}^{-1}$ protein at $\mathrm{DO}_{1.0}$ and $7.42 \mathrm{U}$ $\mathrm{mg}^{-1}$ protein at $\mathrm{DO}_{0.5}$. Under anoxia, superoxide dismutase activity was $10.71 \mathrm{U} \mathrm{mg}^{-1}$ protein (Fig. 6b). Enzyme activity and oxygen consumption showed an inverse relationship. In the control, oxygen consumption was high and the activities of catalase and superoxide dismutase were very low, and this increased with decrease in the DO concentration when the oxygen consumption was low (Fig. 3b). The case was similar in nauplii exposed to different levels of oxygen (Fig. 3b).

\section{Enzyme activity in nauplii under hypoxia and anoxia}

Catalase activity of the nauplii in the control was low (0.47 $\mathrm{U} \mathrm{mg}^{-1}$ protein). However, when the nauplii were exposed to $\mathrm{DO}_{1.0}$ and $\mathrm{DO}_{0.5}$, catalase activity was 1.66
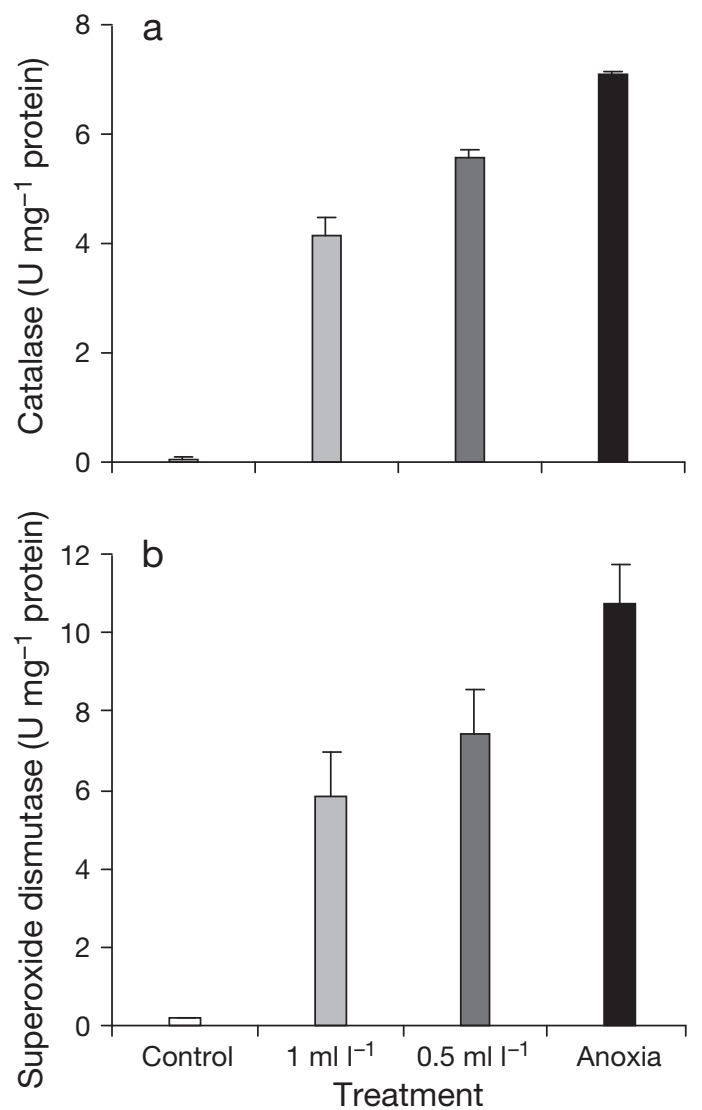

Fig. 6. Balanus amphitrite. Activity of (a) catalase and (b) superoxide dismutase in adults exposed to normoxia (control), hypoxia (0.5 and $\left.1 \mathrm{ml} \mathrm{l}^{-1}\right)$, and anoxia. Error bars: + SD

and $2.75 \mathrm{U} \mathrm{mg}^{-1}$ protein, respectively (1-way ANOVA; $\mathrm{p} \leq$ 0.01) (Fig. 7a). Under anoxic conditions, catalase activity was $6.38 \mathrm{U} \mathrm{mg}^{-1}$ protein (Fig. 7a). Superoxide dismutase showed a similar trend. In the control, the activity was low, $5.86 \mathrm{U} \mathrm{mg}^{-1}$ protein (Fig. $7 b$ ). The activity increased with the decrease in the DO levels (1-way ANOVA; $\mathrm{p} \leq$ 0.02) (Fig. 7b). Under anoxia, superoxide dismutase activity was $34.23 \mathrm{U} \mathrm{mg}^{-1}$ protein (Fig. 7b).

\section{DISCUSSION}

Intertidal habitats are considered to be very dynamic habitats, as they are at the interface of air and water, and Balanus amphitrite is an important inhabitant of this region. The juvenile and adult forms are sessile and the larval forms are planktonic, indicating that they require both pelagic and sessile phases to complete their life cycle. Thus, the tolerance of the nauplii and adults to changes in the DO level is different.

The median mortality time (for $50 \%$ ) of starving and feeding larvae related to oxygen concentrations varied 

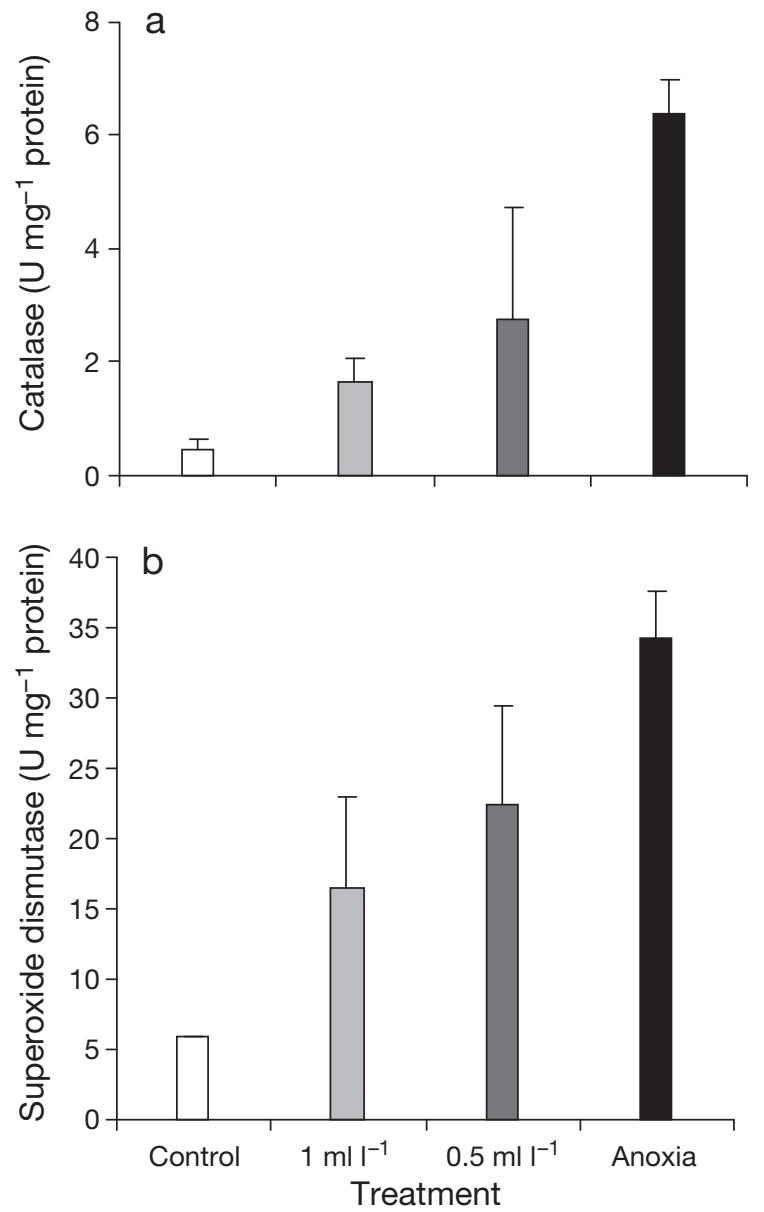

Fig. 7. Balanus amphitrite. Activity of (a) catalase and (b) superoxide dismutase in nauplii exposed to normoxia (control), hypoxia (0.5 and $1 \mathrm{ml} \mathrm{l}^{-1}$ ), and anoxia. Error bars: + SD

with the concentration of DO; feeding larvae tolerated longer durations of hypoxic and anoxic conditions. However, in none of the hypoxic or anoxic conditions, irrespective of nauplii feeding or starving, were cyprids obtained, indicating incomplete naupliar development. This indicates that the requirement of an optimal amount of DO is an important factor in the larval development of Balanus amphitrite. Mortality due to exposure to hypoxia and tolerances to hypoxia differ among species and their life stages (Dorfman \& Westman 1970, Burton et al. 1980, Coutant 1985). The present study reveals that starvation is an important factor in the naupliar development of $B$. amphitrite as the limits of tolerating lower DO concentrations vary with the presence or absence of food. Several studies have indicated a decrease in the feeding rate with a decrease in the DO levels. For example, Cheung et al. (2008) found that in Nassarius festivus, a gastropod, the amount of food consumed was reduced with reduction in the DO level, and oxygen consumption decreased at reduced oxygen levels. Siikavuopio et al. (2007) reported re- duced food intake in the green sea urchin Strongylocentrotus droebachiensis, Jobling (1994) reported reduced food consumption in fishes, Shin et al. (2005) showed reduced food consumption in crab Thalamita danae and Das \& Stickle (1993) reported reduced feeding in the gastropod Stramonita haemastoma when exposed reduced DO levels. These observations were similar to those made in the present study. Thus the varying tolerance levels to hypoxia and anoxia by $B$. amphitrite in the presence of food can be attributed to an insufficient supply of oxygen, which is required to meet all the metabolic needs.

Earlier studies on crustacean larvae have indicated the importance of starvation on larval development and mortality, and reported that the susceptibility to starvation depends upon the species, age of the larvae, and environmental factors (Anger \& Dawirs 1981, Fenaux et al. 1988, Desai \& Anil 2004). Thus the impact of hypoxia and anoxia on larval development can be viewed as an interactive effect that depends on starvation or the availability of food. Studies carried out on the larvae of mussels and oysters (de Zwaan et al. 2001,2002 ) indicated that the tolerance of anoxic conditions is poor in molluscan larvae, which showed $50 \%$ mortality in a shorter duration of exposure to anoxic conditions than Balanus amphitrite in the present study. This indicates that $B$. amphitrite larvae can tolerate hypoxia and anoxia, suggesting that its larval stages have anaerobic metabolic pathways capable of sustaining life for a limited period of time. Thus, an increase in the duration of tolerance to hypoxia and anoxia could be an important factor in the reproductive loss pathway of this species. This suggests that the larvae could tolerate short-term hypoxia and anoxia (hours) associated with low DO levels because of their reduced feeding activity and oxygen consumption; however, this may not be the same for adults, which have higher oxygen consumption, indicating the effect varies with different stages of the life cycle of the organism.

The ingestion rate of Balanus amphitrite nauplii under normoxia showed a difference between the nauplii maintained at low DO concentrations. Feeding was consistent at normal DO levels, depressed under hypoxic conditions, and very low under anoxic conditions, indicating the adverse effect of low DO concentrations in food-rich environments. Gallager (1988), while studying the effect of hypoxia on pediveliger larvae, also observed reduced feeding and ingestion rates under moderate hypoxia, and also showed a reduction in heat dissipation compared to normal conditions. Similar results were also reported for some bivalve larvae (Widdows et al. 1989, Wang \& Widdows 1991).

The oxygen consumption in Balanus amphitrite (adults and nauplii) under normal DO levels was higher than 
under reduced oxygen levels. These observations suggest that $B$. amphitrite reduce their metabolic rate during oxidative stress. A critical oxygen tension level has been observed in the 2 barnacle species $B$. amphitrite and $B$. tintinnabulum tintinnabulum, suggesting that $B$. amphitrite, which inhabits oxygen-deficient areas, was able to regulate itself to much lower concentrations than B. tintinnabulum tintinnabulum (Prasada Rao \& Ganapati 1968).

The above observations indicate that the organisms tolerate the changes in DO levels by controlling their internal physiology. The cells are equipped with an impressive repertoire of antioxidant enzymes, as well as small antioxidant molecules (Yu 1994). These include enzymatic scavengers such as superoxide dismutase, which hastens the dismutation of $\mathrm{O}_{2}{ }^{-{ }^{-}}$and $\mathrm{H}_{2} \mathrm{O}_{2}$, and catalase, which converts $\mathrm{H}_{2} \mathrm{O}_{2}$ to water.

Adult Balanus amphitrite collected from different tidal heights showed different responses to levels of desiccation. The amount of catalase and superoxide dismutase in these adults increased from low (less exposure duration) to high tidal levels (more exposure duration). It is a well known fact that multiple demands are placed on the metabolism of marine organisms both from the stresses imposed by the external environment (e.g. variation in temperature, salinity, oxygen availability, etc.) and from internal physiological drivers, including reproduction and growth. Responses to such demands typically involve changes in flux through selected metabolic pathways, and this generally translates into changes in the activities of pathway enzymes, as they are the machines that run metabolism. The information obtained in the present study suggests the existence of adaptation mechanisms in the barnacles against stress in different niches.

Enhancement of antioxidant defense and increase in the baseline activity of key antioxidant enzymes as well as secondary enzymatic defenses were described in hypoxia- and anoxia-tolerant animals when subjected to environmental and metabolic stress that leads to oxygen limitation (Hermes-Lima \& Zenteno-Savín 2002). Higher activities of superoxide dismutase and catalase were also observed in the marine gastropod Littorina littorea when exposed to anoxia (Pannunzio \& Storey 1998). Higher catalase activity was observed in an estuarine polychaete Laeonereis acuta when exposed to $\mathrm{H}_{2} \mathrm{O}_{2}$ (da Rosa et al. 2007). Seasonal variations in antioxidant enzymes were also reported in adult barnacles of Balanus balanoides in relation to the abundance of polyaromatic hydrocarbons in tissues (Niyogi et al. 2001).

Catalase, unlike superoxide dismutase, was more active in the Balanus amphitrite collected from high tidal regions than from low tidal regions. This enzyme catalyzes the transformation of ROS, i.e. $\mathrm{H}_{2} \mathrm{O}_{2}$, to water. Adult barnacles that were maintained in the laboratory also showed marked differences when incubated in hypoxic and anoxic seawater for $24 \mathrm{~h}$. Controls, which were maintained in aerated seawater for $24 \mathrm{~h}$, did not show higher enzyme activity. The magnitude of change in catalase and superoxide dismutase activity observed in the present study suggests that these 2 antioxidant enzymes could be used as potential biomarkers to classify different ecosystems with respect to stress. Elucidation of genes expressed under such stressed environments needs further validation.

The present study demonstrated response in 2 environments (laboratory and natural) and suggests the importance of environment as a modifying factor in determining the organism's response to hypoxia and anoxia. The response of nauplii also demonstrated a similar trend in enzyme activity when maintained at ambient oxygen concentrations. Overall, the present data demonstrates that the enzymatic make-up of Balanus amphitrite's intermediary metabolism is influenced by both long-term seasonal changes and short-term environmental stress (hypoxia and anoxia). Further studies relating environmental parameters and seasonal variation in the antioxidant enzymes in adults and nauplii collected from the field will provide insights into their physiological means of tolerance under stress.

Acknowledgements. We are grateful to the Director of the National Institute of Oceanography (Goa, India) and to Dr. A. C. Anil, Scientist, for his support and encouragement. We thank all colleagues of the Marine Corrosion and Materials Research Division (MCMRD) for their help during this work. This work is National Institute of Oceanography contribution no. 4566 .

\section{LITERATURE CITED}

Ahmad S (1995) Antioxidant mechanism of enzymes and proteins. In: Ahmad S (ed) Oxidative stress and antioxidant defenses in biology. Chapman \& Hall, New York, p 238-272

Anger K, Dawirs RR (1981) Influence of starvation on the larval development of Hyas areaneus larvae (Decapoda: Majidae). Helgol Meeresunters 38:21-23

Anil AC (1991) Studies on macrofouling ecology of cirripedes in Hamana bay (Japan). DAgr thesis, University of Tokyo

Barnes H, Barnes M (1968) Egg numbers, metabolic efficiency of egg production and fecundity: local and regional variations in a number of common cirripedes. J Exp Mar Biol Ecol 2:135-153

Breitburg DL (1992) Episodic hypoxia in Chesapeake Bay: interacting effects of recruitment, behavior, and physical disturbance. Ecol Monogr 62:525-546

Burton DT, Richardson LB, Moore CJ (1980) Effect of oxygen reduction rate and constant low dissolved oxygen concentrations on two estuarine fish. Trans Am Fish Soc 109: 552-557

Cheung SG, Chan HY, Liu CC, Shin PKS (2008) Effect of prolonged hypoxia on food consumption, respiration, growth and reproduction in marine scavenging gastropod Nas- 
sarius festivus. Mar Pollut Bull 57:280-286

Clare AS, Høeg JT (2008) Balanus amphitrite or Amphiblananus amphitrite? A note on barnacle nomenclature. Biofouling 24:55-57

> Coutant CC (1985) Striped bass, temperature, and dissolved oxygen: a speculative hypothesis for environmental risk. Trans Am Fish Soc 114:31-61

Crisp DJ (1954) The breeding of Balanus porcatas (da Costa). J Mar Biol Assoc UK 33:473-494

da Rosa CE, Bianchini A, Monserrat JM (2007) Antioxidant responses of Laeonereis acuta (Polychaeta) after exposure to hydrogen peroxide. Braz J Med Biol Res 41:117-121

Das T, Stickle WB (1993) Sensitivity of crabs Callinectes sapidus and C. similis and the gastropod Stramonita haemastoma to hypoxia and anoxia. Mar Ecol Prog Ser 98:263-274

> de Zwaan A, Cattani O, Vitali G, Cortesi P (2001) Influence of incubation conditions on the anoxic survival of marine bivalves. Static and semi-static incubations. Mar Ecol Prog Ser 211:169-179

de Zwaan A, Babarro JMF, Monari M, Cattani O (2002) Anoxic survival potential of bivalves: (arte)facts. Comp Biochem Physiol A 131:615-624

> Demple B (1999) Radical ideas: genetic responses to oxidative stress. Clin Exp Pharmacol Physiol 26:64-68

> Desai DV, Anil AC (2004) The impact of food type, temperature and starvation on the larval development of Balanus amphitrite Darwin (Cirripedia: Thoracica). J Exp Mar Biol Ecol 306:113-137

> Desai DV, Anil AC (2005) Recruitment of the barnacle Balanus amphitrite Darwin in a tropical estuary: implications of environmental perturbations, reproduction and larval ecology. J Mar Biol Assoc UK 85:909-920

Devassy VP, Goes JI (1989) Seasonal patterns of phytoplankton biomass and productivity in a tropical estuarine complex (west coast of India). Proc Indian Acad Sci (Plant Sci) 99: 485-501

> Di Giulio RT, Washburn PC, Wenning RJ, Winston GW, Jewell CS (1989) Biochemical responses in aquatic animals: a review of determinants of oxidative stress. Environ Toxicol Chem 8:1103-1123

> Diaz RJ (2001) Overview of hypoxia around the world. J Environ Qual 30:275-281

Dorfman D, Westman J (1970) Responses of some anadromous fishes to varied oxygen concentrations and increased temperatures. Project B-012-NI. New Jersey Water Resources Research Institute, Rutgers University, New Brunswick, NJ

Fenaux L, Cellario C, Rassoulzadegan F (1988) Sensitivity of different morphological stages of the larva of Paracentrotus lividus (Lamarck) to quantity and quality of food. In: Burke D, Mladenov PV, Lambert P, Parsley RL (eds) Echinoderm biology. A. A. Balkema, Rotterdam, p 259-266

Fernando SA (1990) Systematic status of some fouling barnacles of Indian coastal waters. In: Nair KVK, Venugopalan VP (eds) Marine biofouling and power plants. Proceedings of the specialists meeting on marine biodeterioration with reference to power plant cooling systems. IGCAR, Kalpakkam, p 240-250

Foster BA (1970) Responses and acclimation to salinity in the adults of some balanomorph barnacles. Philos Trans R Soc Lond B 256:377-400

Gallager SM (1988) Visual observations of particle manipulation during feeding in larvae of a bivalve mollusc. Zooplankt Behav Symp, 1987, Georgia. Bull Mar Sci 43: 344-365

Halliwell B (1978) Biochemical mechanisms accounting for the toxic action of oxygen on living organisms: the key role of superoxide dismutase. Cell Biol Int Rep 2:113-128
Halliwell B, Gutteridge JMC (1986) Oxygen free radicals and iron in relation to biology and medicine: some problems and concepts. Arch Biochem Biophys 246:501-514

Harned DA, Davenport MS (1990) Water quality trends and basin activities and characteristics for the AlbemarlePamlico estuarine system, NC and VA. Report. USGS, Raleigh, NC, p 90-398

- Hermes-Lima M, Zenteno-Savín T (2002) Animal response to drastic changes in oxygen availability and physiological oxidative stress. Comp Biochem Physiol C 133:537-556

- Howell P, Simpson D (1994) Abundance of marine resources in relation to dissolved oxygen in Long Island Sound. Estuaries 17:394-402

Hurley AC (1973) Fecundity of the acorn barnacle Balanus pacificus pilsbry: a fugitive species. Limnol Oceanogr 18: 386-393

Jobling M (1994) Biotic factors and growth performance. In: Jobling M (ed) Fish bioenergetics, fish and fisheries series, Vol 13. Chapman \& Hall, New York, p 155-201

> Khandeparker L, Anil AC, Raghukumar S (2003) Barnacle larval destination: piloting possibilities by bacteria and lectin interaction. J Exp Mar Biol Ecol 289:1-13

Lewis CLA (1975) Reproductive biology and development of the gooseneck barnacle, Pollicipes polymerus. PhD thesis, University of Alberta, Edmonton

Lopez DA, Gonzalez ML, Vial MV, Simpfendorfer RW (1995) Sublethal effects provoked by the presence of the predator Nucella crassilabrum (Lamarck) upon the mussel Perumytilus purpuratus (Lamarck) in Chile. Rev Chil Hist Nat 68:469-475

> Lowry OH, Rosebrough NJ, Farr AL, Randall RJ (1951) Protein measurement with the Folin phenol reagent. J Biol Chem 193:265-275

> Marklund S, Marklund G (1974) Involvement of the superoxide anion radical in the autoxidation of pyrogallol and a convenient assay for superoxide dismutase. Eur J Biochem 47: 469-474

> Mourente G, Tocher D, Diaz R, Amalia G, Elena P (1999) Relationships between antioxidants, antioxidant enzyme activities and lipid peroxidation products during early development in Dentex dentex eggs and larvae. Aquaculture 179:309-324

Newell RC (1979) Biology of intertidal animals, 3rd expanded edn. Marine Ecological Surveys, Faversham, UK

> Niyogi S, Biswas S, Sarker S, Datta AG (2001) Seasonal variation of antioxidant and biotransformation of enzymes in barnacle, Balanus balanoides, and their relation with polyaromatic hydrocarbons. Mar Environ Res 52:13-26

Paerl HW, Pinckney JL, Fear JM, Peierls BL (1998) Ecosystem responses to internal and watershed organic matter loading: consequences for hypoxia in the eutrophying Neuse River Estuary, North Carolina, USA. Mar Ecol Prog Ser 166: $17-25$

Pannunzio TM, Storey KB (1998) Antioxidant defenses and lipid peroxidation during anoxia stress and aerobic recovery in the marine gastropod Littorina littorea. J Exp Mar Biol Ecol 221:277-292

Prasada Rao GV, Ganapati PN (1968) Respiration as a function of oxygen concentration in intertidal barnacles. Mar Biol 1: 309-310

Pryor WA, Godber SS (1991) Oxidative stress status: an introduction. Free Radic Biol Med 10:173

Richardson TD, Brown KM (1990) Wave exposure and prey size selection in an intertidal predator. J Exp Mar Biol Ecol 142:105-120

Shin PKS, Cheung PH, Yang FY, Cheung SG (2005) Intermittent exposure to reduced oxygen levels affects prey size 
selection and consumption in swimming crab Thalamita danae Stimpson. Mar Poll Bull 51:1003-1009

Siikavuopio SI, Dale T, Mortensen A, Foss A (2007) Effects of hypoxia on feed intake and gonad growth in the green sea urchin, Strongylocentrotus drobachiensis. Aquaculture 266: 112-116

Sinha AK (1972) Colorimetric assay of catalase. Anal Biochem 47:389-394

Southward AJ, Crisp DJ (1965) Activity rhythms of barnacles in relation to respiration and feeding. J Mar Biol Assoc UK 45: 161-185

Stephenson TA, Stephenson A (1972) Life between tide-marks and rocky shores. Freeman, San Francisco, CA

Editorial responsibility: Hans Heinrich Janssen, Oldendorf/Luhe, Germany
Strickland JDH, Parsons TR (1968) A practical handbook of seawater analysis. Bull Fish Res Board Can 167

Wang WX, Widdows J (1991) Physiological responses of mussel larvae Mytilus edulis to environmental hypoxia and anoxia. Mar Ecol Prog Ser 70:223-236

Widdows J, Newell RIE, Mann R (1989) Effects of hypoxia and anoxia on survival, energy metabolism and feeding of oyster larvae (Crassostrea virginica, Gmelin). Biol Bull (Woods Hole) 177:154-166

Winston GW, Di Giulio RT (1991) Prooxidant and antioxidant mechanisms in aquatic organisms. Aquat Toxicol 19:137-161

Yu BP (1994) Cellular defenses against damage from reactive oxygen species. Physiol Rev 74:139-162

Submitted: November 26, 2008; Accepted: June 10, 2009 Proofs received from author(s): August 31, 2009 